\title{
ALI JE NOVA UREDITEV VOLILNIH OKRAJEV ZA DRŽAVNOZBORSKE VOLITVE USTAVNA?
}

Izvirni znanstveni članek COBISS 1.01

DOI: 10.4312/dela.56.131-155

\section{Izvleček}

Državni zbor RS je februarja 2021 sprejel novelo zakona, ki določa volilne enote in volilne okraje, uporabljene za državnozborske volitve. Novela minimalno spreminja ureditev, za katero je Ustavno sodišče RS leta 2018 ugotovilo, da je neustavna. V raziskavi smo preverili, v kolikšni meri nova ureditev izpolnjuje zakonska merila in odpravlja neustavno stanje. Primerjalna analiza, v katero sta poleg stare in nove ureditve vključena še dva predloga ureditve volilnih okrajev, ki ju je leta 2019 oblikovala strokovna skupina, kaže več pomanjkljivosti nove ureditve. Ta sicer odpravlja problem velikostno najbolj izstopajočih volilnih okrajev, ne rešuje pa problema njihove geografske nezaokroženosti. Posledično se lahko zgodi, da bo nova ureditev znova predmet ustavne presoje.

Ključne besede: volilna geografija, volilni okraji, Slovenija, Državni zbor Republike Slovenije

\footnotetext{
* Oddelek za geografijo, Filozofska fakulteta Univerze v Ljubljani, Aškerčeva 2, SI-1000 Ljubljana e-pošta: bostjan.rogelj@ff.uni-lj.si
} 


\title{
IS THE NEW REGULATION OF CONSTITUENCIES FOR PARLIAMENTARY ELECTIONS IN SLOVENIA CONSTITUTIONAL?
}

\begin{abstract}
In February 2021, the National Assembly of the Republic of Slovenia adopted an amendment to the law determining the electoral districts used for parliamentary elections in Slovenia. The amendment minimally changes the system of electorates, which the Constitutional Court of the Republic of Slovenia found to be unconstitutional in 2018. For this paper, we examined the extent to which the new system meets the legal criteria and remedies the unconstitutional situation. The comparative analysis, which includes the old and the new systems as well as two proposals formed by an expert group in 2019, has highlighted several shortcomings of the new system. The new system eliminates the vast differences in district sizes but does not solve the problem of geographically inconsistent constituencies. As a result, the new system may again be subject to constitutional review.
\end{abstract}

Keywords: electoral geography, electoral districts, Slovenia, National Assembly of the Republic of Slovenia

\section{UVOD}

Volilne enote so eden najpomembnejših elementov volilnega sistema (Lijphart, 1994). V volilni sistem so navadno vključene zaradi želje po enakomernejši prostorski porazdelitvi mandatov, tesnejši povezanosti volivcev in poslancev ter lažji organizaciji in izvedbi volitev (Krašovec, 2007; Norris, 2004). Ureditev volilnih enot enako kot drugi elementi volilnega sistema pripomore k legitimnosti volilnega sistema. Ureditev, ki del volilnega telesa postavlja v neenakopraven položaj oziroma ga diskriminira, lahko vodi v odtujenost volivcev in volilno neaktivnost. Ta se navadno kaže v nizki volilni udeležbi ali večjem deležu neveljavnih glasovnic (McAllister, Makkai, 1993; Power, Garand, 2007). Oba dejavnika spodkopavata legitimnost izvoljenih oblasti, s tem pa se zmanjšuje tudi stopnja sprejemanja vladnih odločitev (Hadjar, Beck, 2010).

Državni zbor RS je februarja 2021 po več kot dveletni razpravi sprejel novelo Zakona o določitvi volilnih enot za volitve poslancev v državni zbor (v nadaljnjem besedilu ZDVEDZ). Sprejetje novele je končni rezultat reforme volilne zakonodaje, ki jo je sprožila odločba Ustavnega sodišča o neustavnosti ureditve volilnih okrajev iz leta 2018. Ustavni sodniki so ugotovili, da so problematične tako velike razlike v številu volivcev med volilnimi okraji kot tudi njihova geografska nezaokroženost (Ustavno sodišče RS, 2018). 
Odločitev Ustavnega sodišča RS je sprožila reformo volilne zakonodaje, v okviru katere sta se oblikovala dva predloga. Prvi je predvideval temeljitejšo spremembo volilnega sistema $\mathrm{z}$ uvedbo relativnega prednostnega glasu in odpravo volilnih okrajev. Drugi je predvideval le preoblikovanje meja volilnih okrajev. Ministrstvo za javno upravo je za pripravo drugega predloga oblikovalo strokovno delovno skupino, ki je v letu 2019 pripravila tri predloge nove ureditve volilnih okrajev (Rogelj in sod., 2019a; 2019b). Po zamenjavi vlade marca 2020 je pripravo nove zakonodaje prevzela nova vladna koalicija pod vodstvom Slovenske demokratske stranke (SDS). Medtem ko je strokovna skupina zagovarjala temeljito preoblikovanje ureditve volilnih okrajev, je stranka SDS zagovarjala minimalne spremembe (MMC RTV SLO, 2021). Predstavniki SDS-a so trdili, da je veljavna ureditev v večji meri ustrezna, problematična naj bi bila le peščica velikostno (glede na število volivcev) močno odstopajočih volilnih okrajev. Skladno z omenjenim stališčem je Ministrstvo za javno upravo (MJU) v začetku leta 2021 pripravilo predlog, ki je predvidel spremembo meja štirinajstih volilnih okrajev in tri popravke meja volilnih enot.

V središču raziskave je ocena ustavnosti sprejete ureditve. Zanima nas, ali ta odpravlja neustavno stanje oziroma v kolikšni meri izpolnjuje zakonska določila o velikosti in geografski zaokroženosti volilnih okrajev. $\mathrm{V}$ ta namen smo izvedli primerjalno prostorsko in statistično analizo, $\mathrm{v}$ kateri smo novo ureditev primerjali s staro ureditvijo in $\mathrm{z}$ dvema predlogoma, ki ju je pripravila strokovna skupina.

\section{VOLILNI OKRAJI V DRŽAVNOZBORSKEM VOLILNEM SISTEMU}

Ozemlje države je za potrebe državnozborskih volitev razdeljeno na osem volilnih enot (slika 2). Vsaka od njih je razdeljena na 11 volilnih okrajev (skupaj je država razdeljena na 88 volilnih okrajev). Medtem ko v volilnih enotah poteka primarna medstrankarska delitev mandatov, so volilni okraji uporabljeni za znotrajstrankarsko delitev mandatov (Grad, 2004).

Zakon o volitvah v državni zbor (v nadaljnjem besedilu ZVDZ) določa, da morajo imeti volilni okraji približno enako število prebivalcev in da je pri njihovem oblikovanju treba upoštevati geografsko zaokroženost ter skupne kulturne in druge značilnosti (Zakon o volitvah ..., 2017). Pri tem je pomembno, da zakon nikjer ne določa maksimalno dovoljenega odstopanja v številu prebivalcev. Prav tako ne določa, katera merila je treba upoštevati, da bi zadostili merilu geografske zaokroženosti.

Prvi osnutek ZDVEDZ iz leta 1992 je predvideval oblikovanje približno enako velikih volilnih okrajev (predlog je predvideval največ 10-odstotno odstopanje). Politika je omenjenemu predlogu zaradi delitve večine občin močno nasprotovala in v parlamentarni postopek vložila dopolnilo, na podlagi katerega so se pri oblikovanju volilnih okrajev upoštevale geografska zaokroženost in skupne značilnosti ozemlja. V praksi je 
to pomenilo, da so meje volilnih okrajev, če je bilo to mogoče, uskladili z mejami takratnih občin (Rogelj, 2011, str. 92). S tem so ustvarili geografsko relativno homogene in kompaktne, velikostno pa zelo heterogene volilne okraje (preglednica 1, slika 1).

Ureditev volilnih enot in volilnih okrajev je bila od vsega začetka deležna številnih kritik (Gaber, 1996; Pogorelec, 1998; Ribičič, 1996). Kljub temu vse od sprejetja obeh temeljnih zakonov leta 1992 ni doživela večjih sprememb. Nekaj manjših popravkov je bilo narejenih leta 2004, ko so meje nekaterih okrajev uskladili z novimi občinskimi mejami (največje spremembe so bile na območju občin Železniki in Novo mesto). O ustavnosti ureditve je trikrat presojalo tudi Ustavno sodišče RS. V prvih dveh primerih (v letih 1992 in 2003) so sodniki presodili, da ureditev ni neustavna (Ustavno sodišče RS, 2003; 1992), v tretjem so presodili, da je 4. člen ZDVEDZ neskladen z Ustavo RS.

K omenjeni odločitvi sta pripomogla predvsem dva dejavnika. Prvi so spremembe v prostorski razporeditvi prebivalstva, zaradi katerih so se razlike v številu prebivalcev/ volivcev med volilnimi okraji še dodatno povečale (preglednica 1, slika 1). Številne reforme lokalne samouprave po letu 1992 so drugi pomemben dejavnik. Zaradi njih je v številnih primerih prišlo do neusklajenosti meja volilnih okrajev z občinskimi mejami.

Slika 1: Stara ureditev (2004-2021) - Indeks velikosti volilnih okrajev glede na velikost povprečnega volilnega okraja (19.358 volivcev).

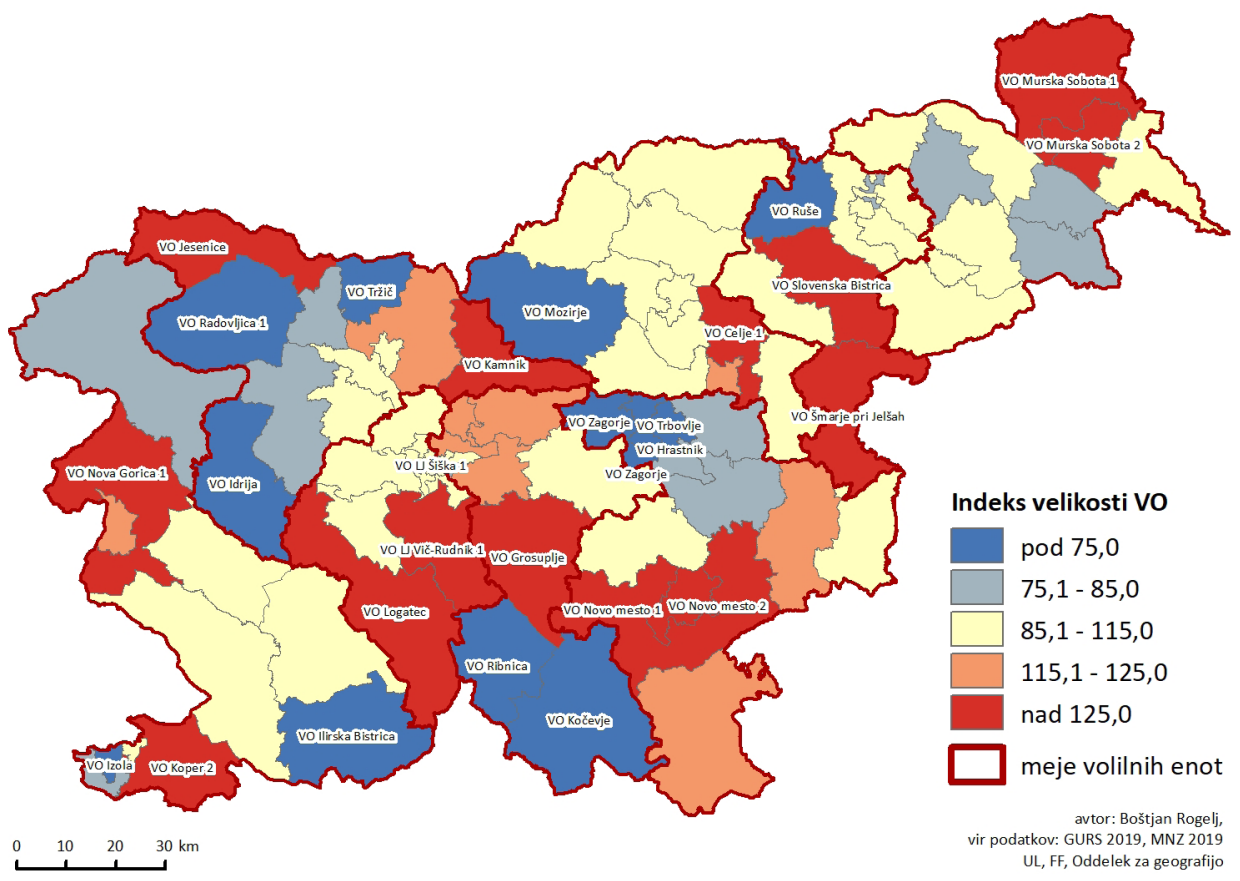


Preglednica 1: Velikost volilnih okrajev v letih 1992 in 2019 (vir podatkov: MNZ, 2019; ZRSS, 1994).

\begin{tabular}{|l|c|c|}
\hline & $\mathbf{1 9 9 2}$ & $\mathbf{2 0 1 9}$ \\
\hline Povprečna velikost volilnega okraja (št. volivcev) & 16.970 & 19.358 \\
\hline Velikost najmanǰ̌ega volilnega okraja (št. volivcev) & $\begin{array}{c}8.313 \\
\text { Hrastnik }\end{array}$ & $\begin{array}{c}7.945 \\
\text { Hrastnik }\end{array}$ \\
\hline Odstopanje najmanjšega volilnega okraja od povprečja & $-51,0 \%$ & $-59,0 \%$ \\
\hline Velikost največjega volilnega okraja (št. volivcev) & $\begin{array}{c}25.383 \\
\text { Murska Sobota I }\end{array}$ & $\begin{array}{c}31.694 \\
\text { Grosuplje }\end{array}$ \\
\hline Odstopanje največjega volilnega okraja od povprečja & $+49,9 \%$ & $+63,7 \%$ \\
\hline $\begin{array}{l}\text { Razlika med največjim in najmanjšim volilnim okrajem } \\
\text { (št. volivcev) }\end{array}$ & 17.070 & 23.749 \\
\hline $\begin{array}{l}\text { Število volilnih okrajev, ki od povprečja odstopajo } \\
\text { za manj kot 15 \% (-/+ 15 \%) }\end{array}$ & 45 & 40 \\
\hline
\end{tabular}

\section{METODOLOGIJA DELA}

Analiza temelji na podatkih Centralnega registra prebivalstva (CRP) o številu volivcev po hišnih številkah, ki ga vodi Ministrstvo za notranje zadeve RS (MNZ, 2019), prostorskih podatkovnih slojih Registra prostorskih enot (RPE), ki ga vodi Geodetska uprava RS (GURS, 2021), in prostorskih podatkovnih slojih, ki jih je pripravila strokovna delovna skupina (Rogelj in sod., 2019a; 2019b). Podatki o volivcih odražajo stanje aprila 2019 (povprečni volilni okraj je takrat štel 19.358 volivcev), prostorski podatkovni sloji pa stanje leta 2019 (podatki strokovne delovne skupine) oziroma 2021 (podatki Registra prostorskih enot). Za potrebe raziskave smo podatke o volivcih agregirali na ravni različnih prostorskih enot (prostorski okoliši, naselja, občine, volilni okraji). Na tem mestu velja opozoriti, da so oblikovalci nove ureditve volilnih okrajev operirali z novejšimi podatki o številu volivcev (verjetno iz druge polovice leta 2020). Zaradi intenzivnih medobčinskih selitev v prvem obdobju epidemije COVID-a (Razpotnik, 2020) se omenjeni podatki nekoliko razlikujejo od podatkov, uporabljenih $\mathrm{v}$ analizi.

Analizirali smo štiri ureditve volilnih okrajev:

- ureditev, ki je veljala od leta 2004 do leta 2021 (stara ureditev);

- ureditev, ki velja od leta 2021 (nova ureditev);

- ureditev, ki jo je predlagala strokovna skupina leta 2019 (predlog strokovne skupine);

- alternativno ureditev, ki jo je predlagala strokovna skupina leta 2019 (alternativni predlog strokovne skupine). 
S pomočjo izbranih kvantitativnih kazalcev (uporabili smo različne mere razpršenosti, razmerja in indekse) smo preverili, v kolikšni meri posamezna ureditev sledi zakonskemu določilu, da naj bi imeli volilni okraji približno enako število prebivalcev/volivcev. Oceno geografske zaokroženosti volilnih okrajev smo naredili na podlagi prostorske analize usklajenosti njihovih meja z mejami obstoječih upravno-teritorialnih enot (mestnih četrti, krajevnih skupnosti, naselij in občin).

\section{GLAVNE ZNAČILNOSTI NOVE UREDITVE VOLILNIH OKRAJEV (2021)}

Državni zbor RS je 16. februarja 2021 sprejel novelo ZDVEDZ. Z njo so bile spremenjene meje štirinajstih volilnih okrajev (VO) in petih volilnih enot (VE).

Spremembe meja volilnih enot (Zakon o spremembah in dopolnitvah ..., 2021):

1. VE 4: iz nje se izloči območje volilnega okraja Litija, ki obsega občini Litija in Šmartno pri Litiji, ter naselji Ravne nad Šentrupertom in Kostanjevica v občini Šentrupert in naselja Pusti Javor, Radanja vas, Sela pri Sobračah, Sobrače in Vrh pri Sobračah v občini Ivančna Gorica;

Slika 2: Nova ureditev volilnih enot (2021).

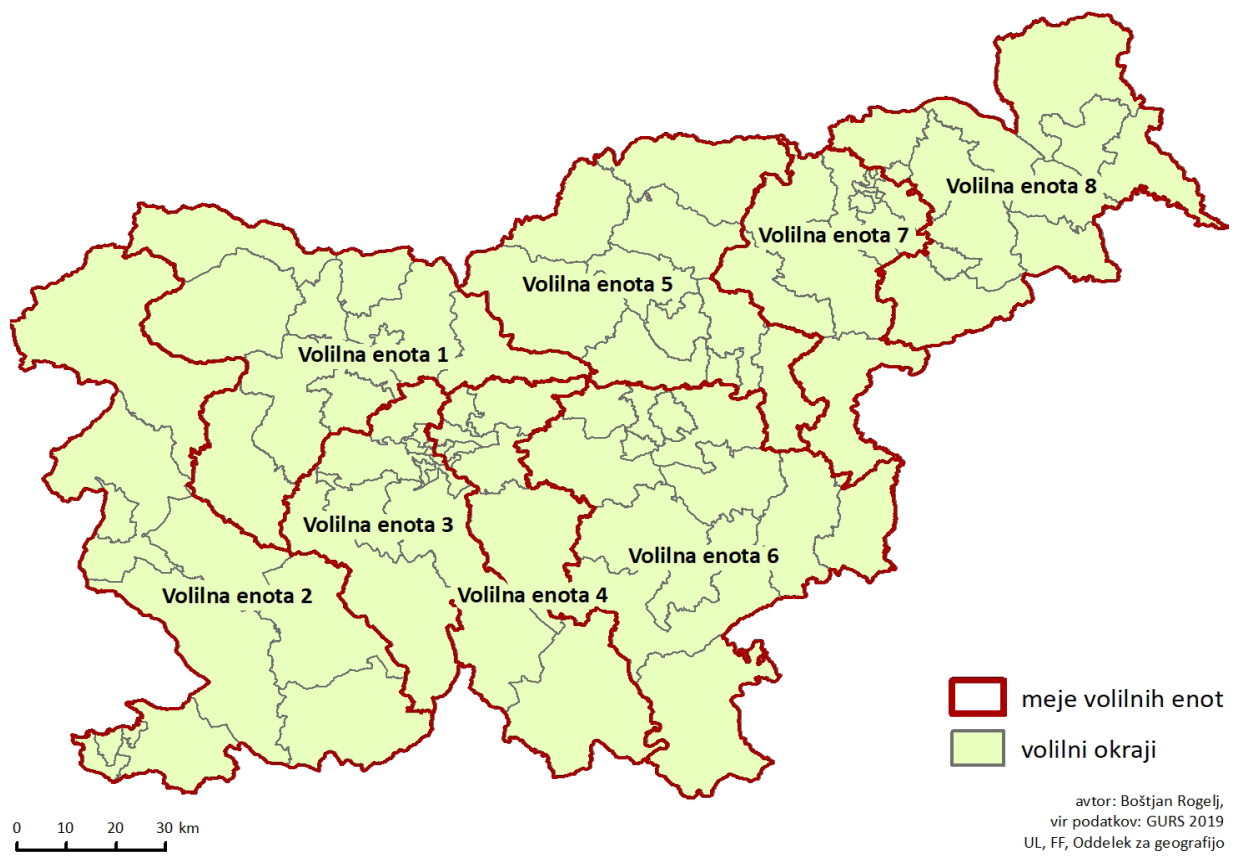


2. VE 5: iz nje se izloči del naselij Knezdol in Vrhe v občini Trbovlje;

3. VE 6: priključi se ji občini Litija in Šmartno pri Litiji, naselji Ravne nad Šentrupertom in Kostanjevica v občini Šentrupert ter naselja Pusti Javor, Radanja vas, Sela pri Sobračah, Sobrače, Vrh pri Sobračah v občini Ivančna Gorica ter dela naselij Knezdol in Vrhe v občini Trbovlje;

4. VE 7: izloči se del občine Pesnica, ki obsega naselja Dragučova, Ložana, Pernica, Vosek in Vukovje ter del naselja Kušernik;

5. VE 8: priključi se ji del občine Pesnica, ki obsega naselja Dragučova, Ložana, Pernica, Vosek in Vukovje ter del naselja Kušernik.

Volilni okraj Litija je bil iz VE 4 prestavljen v VE 6, ker je bilo treba zmanjšati razliko v velikosti volilnih enot. Zaradi različnih demografskih trendov se je razlika med največjo (VE 4) in najmanjšo (VE 6) volilno enoto v zadnjih dveh desetletjih močno povečala (leta 2019 je znašala že 11 odstotnih točk). Posledično je bila ogrožena enaka volilna pravica, skladno s katero mora enega poslanca voliti približno enako število volivcev. S premikom volilnega okraja Litija se je omenjena razlika občutno zmanjšala (na 4,4 odstotne točke).

Slika 3: Nova ureditev volilnih okrajev (2021).

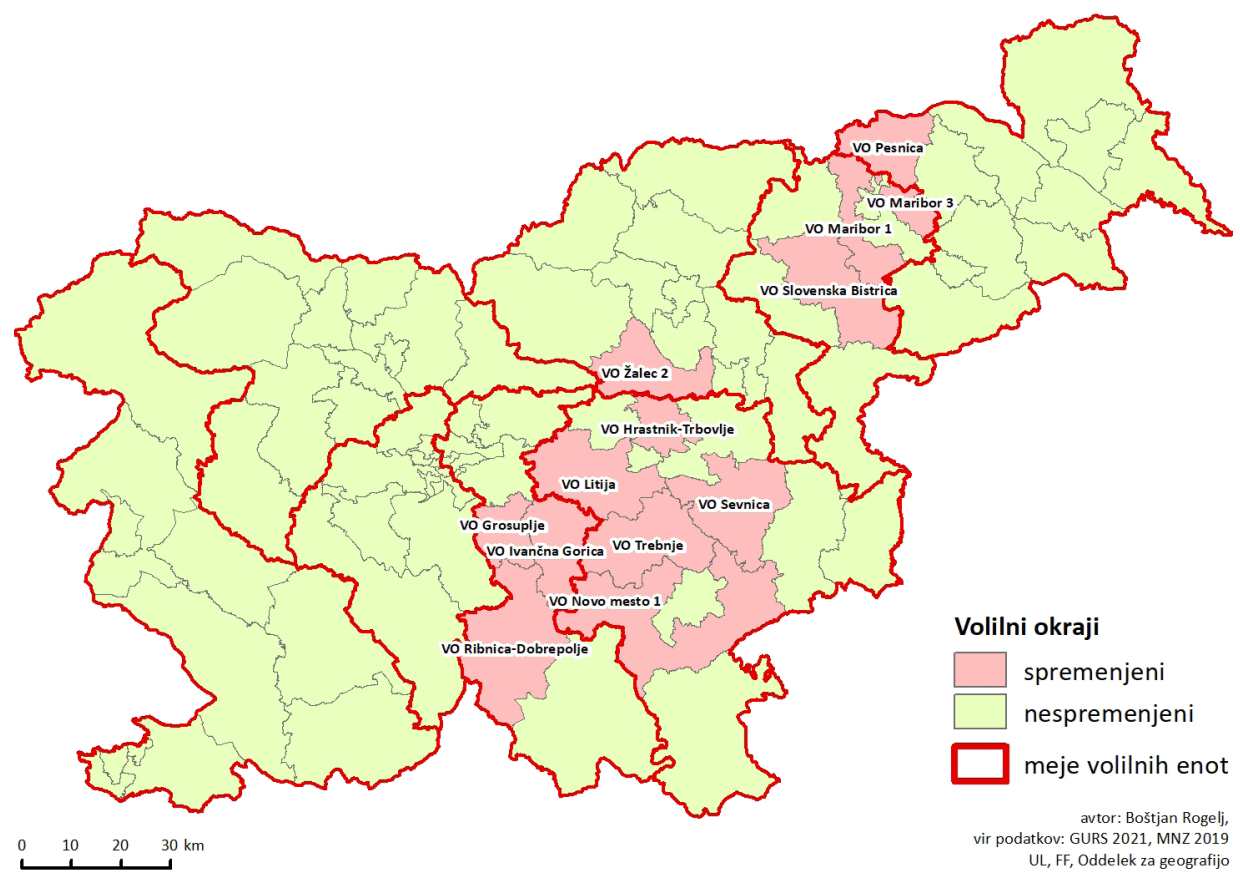


Preostale spremembe so posledica uskladitve meja volilnih enot $\mathrm{z}$ občinskimi mejami. Pri tem pa je zanimivo, da je nova ureditev povzročila novo neskladje, saj je občina Ivančna Gorica po novem razdeljena med VE 4 in VE 6. V slednjo spada krajevna skupnost Sobrače, ki je bila v preteklosti del občine Litija, z reformo lokalne samouprave pa je bila priključena občini Ivančna Gorica.

Spremembe volilnih okrajev (Zakon o spremembah in dopolnitvah ..., 2021):

1. VO 4002 (Ribnica): se poveča za območje občine Dobrepolje;

2. VO 4003 (Grosuplje): se zmanjša na območje občine Grosuplje;

3. oblikuje se nov VO 4004 (Ivančna Gorica): ki obsega del občine Ivančna Gorica (brez naselij Pusti Javor, Radanja vas, Sela pri Sobračah, Sobrače, Vrh pri Sobračah);

4. VO 5005 (Žalec II) se zmanjša za majhen del občine Trbovlje (del naselij Knezdol in Vrhe);

5. VO 6002 (Novo mesto I): se zmanjša za območje občine Škocjan;

6. VO 6004 (Trebnje): se poveča za del občine Šentrupert (naselja Ravne nad Šentrupertom in Kostanjevica ter Mali Cirnik pri Šentjanžu);

7. VO 6007 (Sevnica): se poveča za občino Škocjan ter zmanjša za del občine Šentrupert (naselje Mali Cirnik pri Šentjanžu);

8. VO 6009 (Litija): se zmanjša za del občine Šentrupert (naselji Ravne nad Šentrupertom in Kostanjevica);

9. VO 6010 (Trbovlje-Hrastnik): se poveča za območje občine Hrastnik, hkrati se mu doda del naselij Knezdol in Vrhe v občini Trbovlje;

10. nekdanji VO 6009 (Hrastnik) se ukine;

11. VO 7002 (Slovenska Bistrica): se zmanjša za del občine Slovenska Bistrica (krajevni skupnosti Pragersko ter Spodnja in Zgornja Polskava);

12. VO 7005 (Maribor I): se poveča za del občine Slovenska Bistrica (krajevne skupnosti Pragersko ter Spodnja in Zgornja Polskava);

13. VO 7007 (Maribor III): se zmanjša za del občine Pesnica (naselja Dragučova, Ložana, Pernica, Vosek in Vukovje ter del naselja Kušernik);

14. VO 8008 (Pesnica): se poveča za del občine Pesnica (naselja Dragučova, Ložana, Pernica, Vosek in Vukovje ter del naselja Kušernik).

V grobem lahko spremembe meja volilnih okrajev razdelimo v dve skupini. V prvi so spremembe, ki so nastale zaradi želje po zmanjševanju velikih razlik v velikosti volilnih okrajev. Z razkosanjem VO 4003 (Grosuplje) in zmanjšanjem VO 7002 (Slovenska Bistrica) sta se občutno zmanjšala dva največja volilna okraja v državi. Z oblikovanjem VO 6010 (Trbovlje-Hrastnik) in povečanjem VO 4002 Ribnica sta se povečala najmanjša okraja $\mathrm{v}$ državi.

V drugo skupino spadajo spremembe, ki so nastale zaradi uskladitve meja volilnih okrajev z občinskimi mejami. Pri tem velja opozoriti, da je bila odpravljena le peščica neskladij. Pred spremembo ureditve je bilo v državi 24 občin, katerih meje niso bile usklajene z mejami volilnih okrajev (Rogelj, 2012). Nova ureditev je odpravila le tri neskladja, in sicer na območju občin Pesnica, Trbovlje in Šentrupert. 
Poseben primer je premik občine Škocjan iz VO 6002 (Novo mesto I) v VO 6007 (Sevnica). Razlogi zanj niso jasni. Res je, da so $\mathrm{z}$ omenjeno potezo uravnotežili velikost obeh (prvi je spadal med večje, drugi pa med manjše okraje), toda dejstvo, da nekateri bolj izstopajoči volilni okraji niso bili preoblikovani, kaže na to, da je bil premik verjetno povezan s partikularnimi interesi največje koalicijske stranke.

Slika 4: Nova ureditev volilnih okrajev (2021) - Indeks velikosti volilnih okrajev glede na velikost povprečnega volilnega okraja (19.358 volivcev).

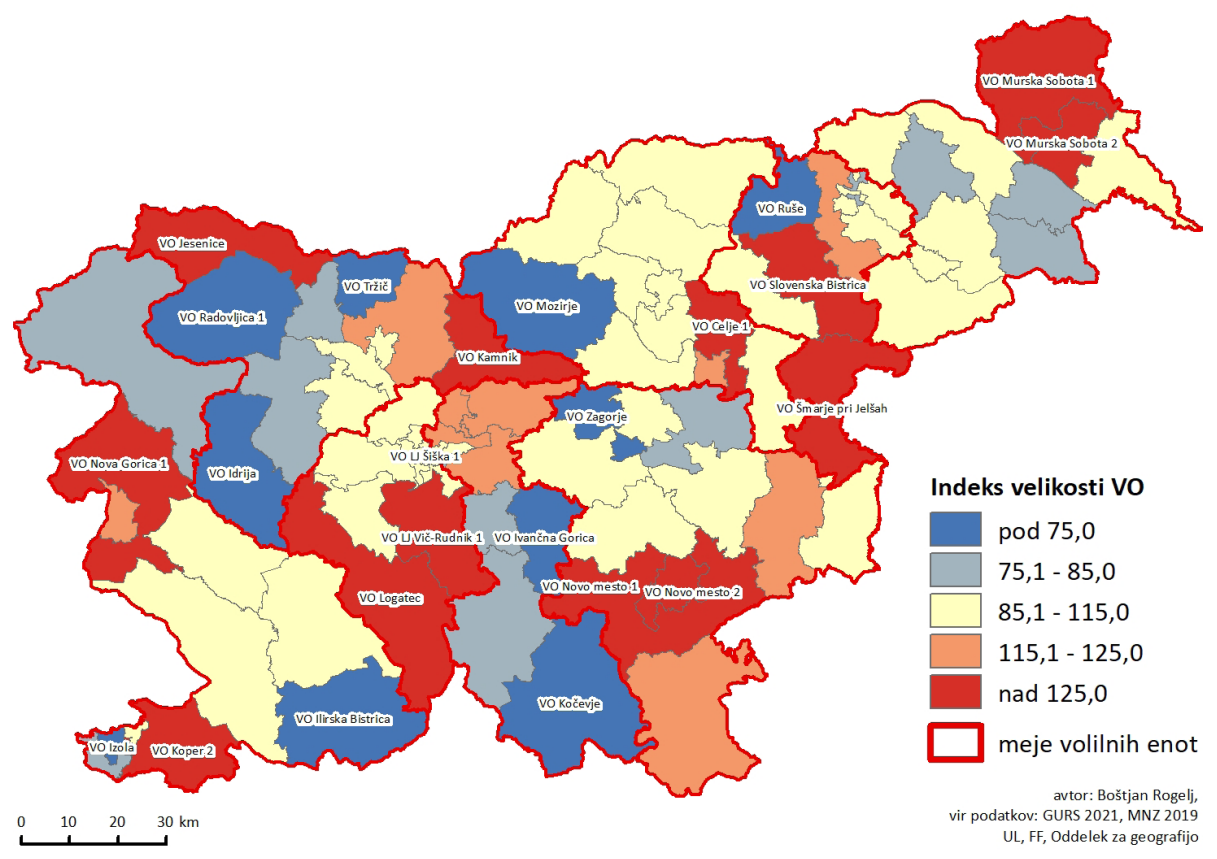

\section{GLAVNE ZNAČILNOSTI PREDLOGA STROKOVNE SKUPINE (2019)}

Strokovna skupina je v času delovanja (leta 2019) pripravila tri predloge nove ureditve volilnih okrajev. Prvotni predlog je predvideval relativno majhna $(-/+15 \%)$ odstopanja $\mathrm{v}$ številu volivcev in uskladitev meja volilnih okrajev z mejami uveljavljenih prostorskih enot (občin, naselij, četrtnih/krajevnih/vaških skupnosti). Politične stranke nad predlogom niso bile navdušene, saj je predvideval temeljito preoblikovanje takrat veljavne ureditve. V okviru pogajanj o spremembi volilnega sistema pod okriljem predsednika države je bilo sklenjeno, da se oblikuje nov predlog, ki bo dovoljeval večja odstopanja v velikosti. 
Slika 5: Predlog ureditve volilnih okrajev, ki ga je pripravila strokovna skupina (2019).

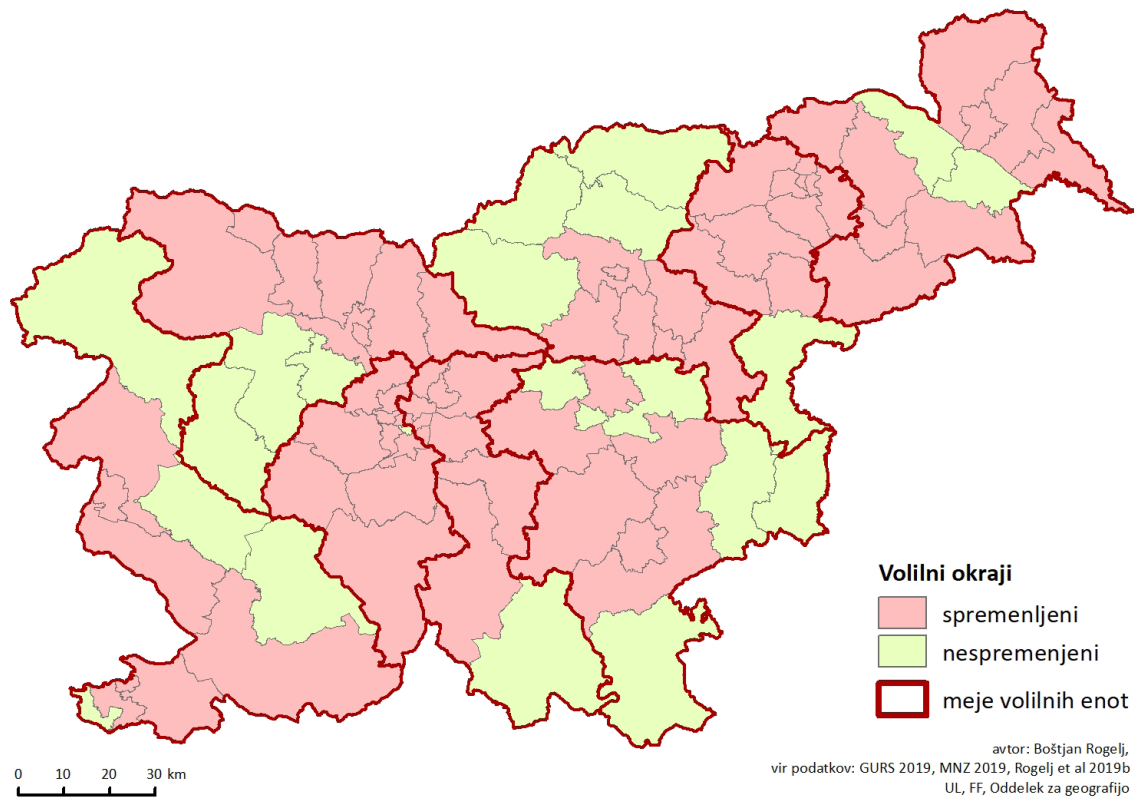

Slika 6: Predlog strokovne skupine (2019): Indeks velikosti volilnih okrajev glede na velikost povprečnega volilnega okraja (19.358 volivcev).

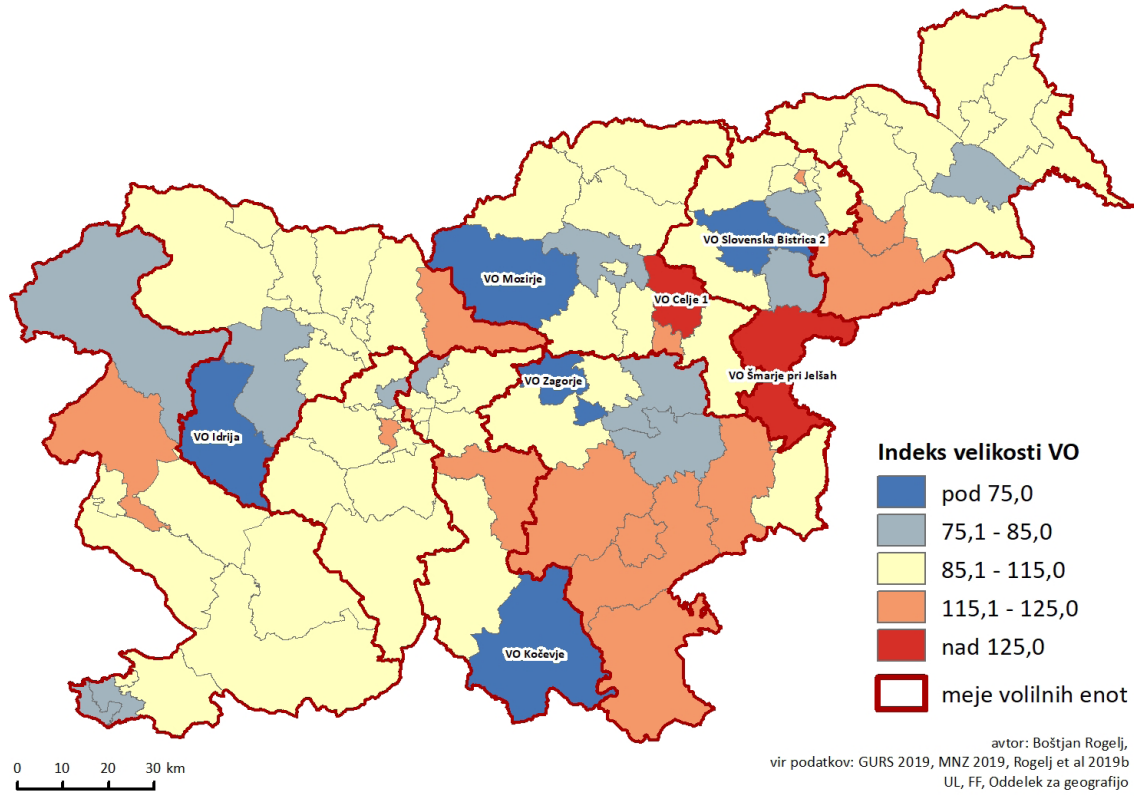


Slika 7: Alternativni predlog ureditve volilnih okrajev, ki ga je pripravila strokovna skupina (2019).

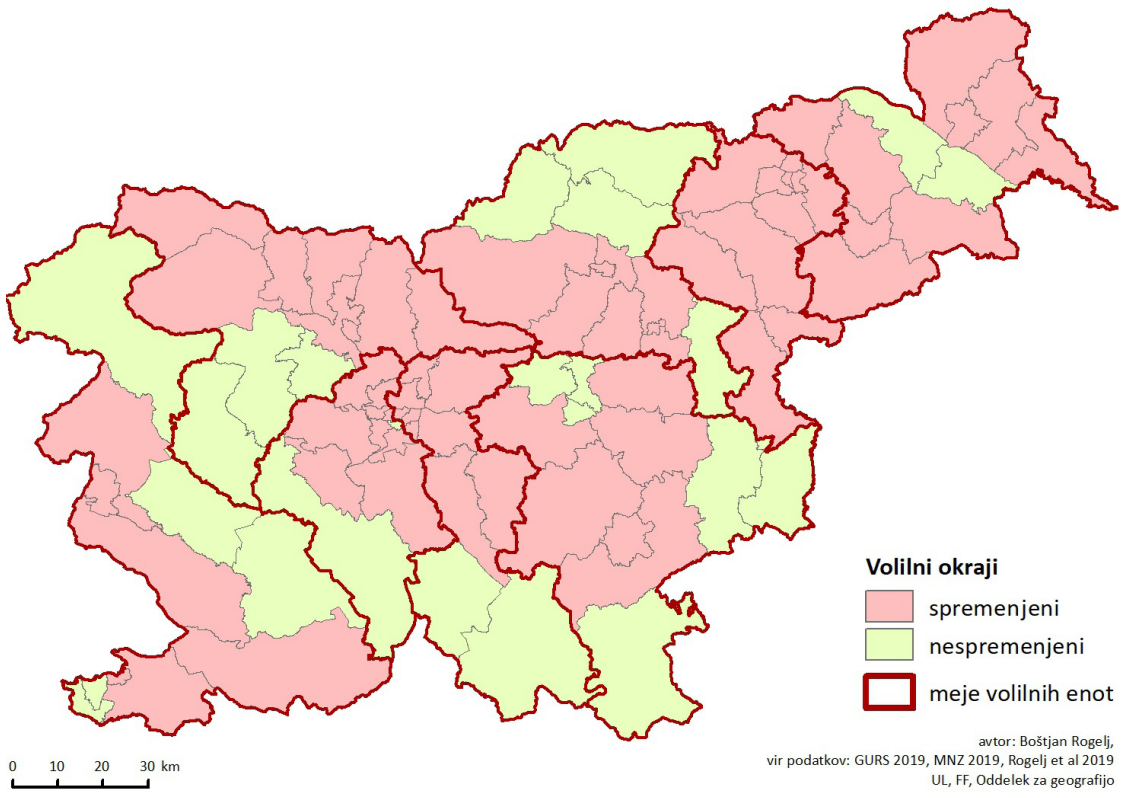

Slika 8: Alternativni predlog strokovne skupine (2019): Indeks velikosti volilnih okrajev glede na velikost povprečnega volilnega okraja (19.358 volivcev).

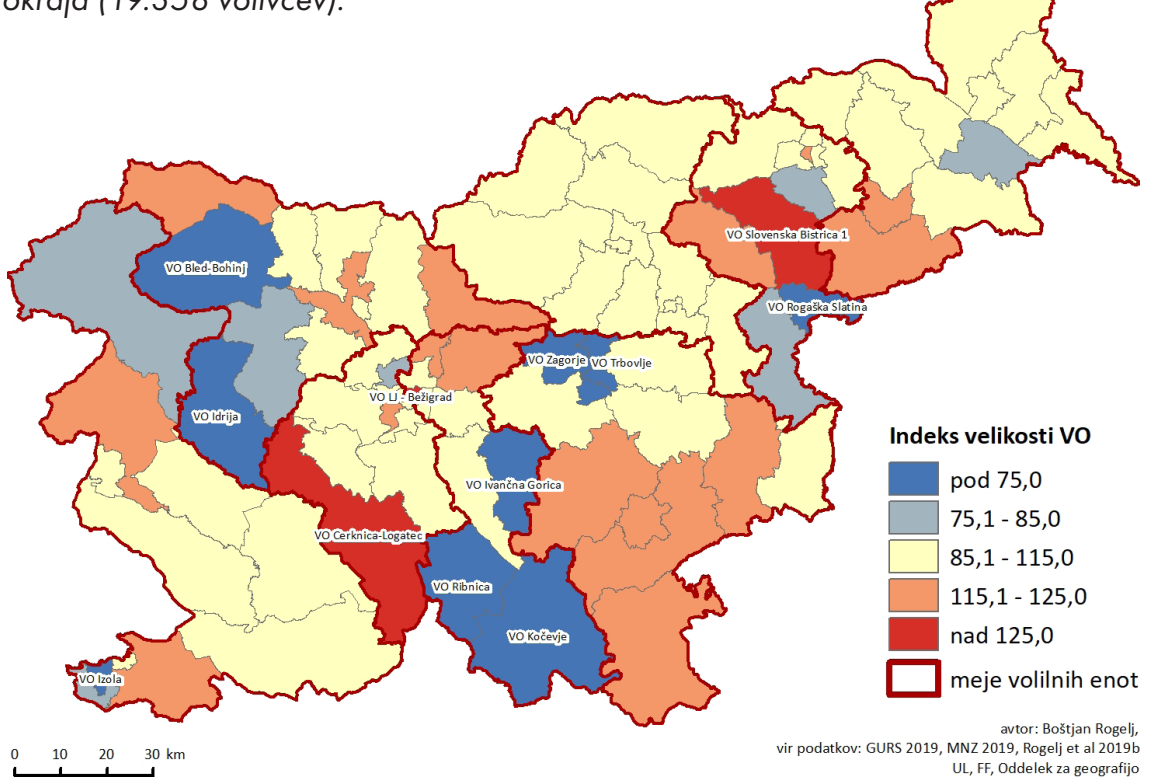


Strokovna skupina je pripravila dva predloga, ki sta temeljila na enakih izhodiščih:

- Velikost volilnih okrajev je bila določena na podlagi števila volivcev.

- Velikost volilnega okraja naj ne bi odstopala od povprečnega volilnega okraja za več kot $25 \%$. V izjemnih primerih se zaradi spoštovanja načela geografske zaokroženosti dovolijo tudi večja odstopanja v velikosti.

- Meje volilnih okrajev se določajo na podlagi meja občin. V primeru delitve občin se upoštevajo meje naselij. Pri naseljih z več kot 24.197 volivci (Celje, Kranj, Ljubljana in Maribor) se meje volilnih okrajev uskladijo z mejami krajevnih/ mestnih/četrtnih skupnosti.

- V mestni občini Ljubljana se pri oblikovanju volilnih okrajev v izjemnih primerih upoštevajo meje prostorskih okolišev.

Oba predloga sta vključevala spremembo meja volilnih enot. Poleg sprememb, vključenih v novelo Zakona o določitvi volilnih enot za volitve poslancev v DZ, sta predvidevala še dve manjši spremembi. V mestni občini Ljubljana bi bilo celotno območje četrtne skupnosti Posavje vključeno v VE 4 . V omenjeno volilno enoto bi bilo vključeno tudi celotno območje občine Ivančna Gorica.

Predloga sta se razlikovala v dovoljenih velikostnih odstopanjih in stopnji spoštovanja načela geografske zaokroženosti. Po prvem predlogu (v primerjalni analizi imenovan predlog strokovne skupine) bi le sedem volilnih okrajev za več kot $25 \%$ odstopalo od velikosti povprečnega volilnega okraja (le eden bi odstopal za več kot $30 \%$ ). Predlog je predvideval delitev trinajstih občin, med katerimi bi bile štiri (Brezovica, Grosuplje, Slovenska Bistrica in Vrhnika) manjše od velikosti največjega dovoljenega volilnega okraja. Drugi predlog (v primerjalni analizi imenovan alternativni predlog strokovne skupine) je odpravil delitev omenjenih občin z oblikovanjem večjega števila velikostno bolj izstopajočih volilnih okrajev (dvanajst okrajev bi odstopalo za več kot $25 \%$, od tega šest za več kot $30 \%$ ). Pri obeh predlogih bi na območju večjih mestnih občin (Ljubljana, Maribor, Celje, Kranj in Velenje) meje volilnih okrajev sledile mejam naselij ter četrtnih, mestnih in krajevnih skupnosti.

\section{REZULTATI PRIMERJALNE ANALIZE}

Izbrani kvantitativni kazalci in grafične predstavitve (preglednica 2, slike 1, 4, 6, 8 in 9), s katerimi smo preverili spoštovanje zakonskega določila, po katerem naj bi imeli volilni okraji približno enako število prebivalcev/volivcev, kažejo na velike razlike med analiziranimi ureditvami. Predvsem med staro in novo ureditvijo ter obema predlogoma strokovne skupine. Nova ureditev je s preoblikovanjem dveh najmanjših in dveh največjih volilnih okrajev občutno zmanjšala razliko med najbolj odstopajočima volilnima okrajema, zelo malo pa je pripomogla k odpravi velike velikostne razpršenosti. Iz 
slik 4 in 9 je razvidno, da nova ureditev ohranja veliko volilnih okrajev, ki za več kot 25 $\%$ odstopajo od povprečja, in da jih le slaba polovica od povprečja odstopa za manj kot $15 \%$. Iz rezultatov je razvidno, da so tako za staro kot novo ureditev veliki odmiki od povprečne velikosti prej pravilo kot izjema. Nasprotno lahko trdimo za oba predloga strokovne skupine, ki sta poleg velikih velikostnih razlik odpravila tudi veliko velikostno razpršenost (slike 6, 8 in 9). Osnovni predlog je predvidel le sedem okrajev, ki bi za več kot $25 \%$ odstopali od povprečja, od tega le eden (Šmarje pri Jelšah) za več kot 30 $\%$. Skoraj dve tretjini okrajev bi od povprečja odstopalo za manj kot $15 \%$. Alternativni predlog je predvidel nekoliko večja odstopanja, saj bi ohranil oziroma ustvaril nekaj zelo majhnih volilnih okrajev (Ribnica, Rogaška Slatina, Izola in Ivančna Gorica). Posledično so izračunani kazalci razpršenosti slabši kot za osnovni predlog, vendar še vedno bistveno boljši kot pri stari oziroma novi ureditvi (preglednica 2).

Preglednica 2: Izbrani kazalci velikostne razpršenosti volilnih okrajev $v$ analiziranih ureditvah (vir: lastni izračuni na podlagi podatkov GURS, 2021; MNZ, 2019; Rogelj in sod., 2019a; 2019b).

\begin{tabular}{|c|c|c|c|c|}
\hline Kazalec & $\begin{array}{c}\text { Stara } \\
\text { ureditev }\end{array}$ & $\begin{array}{c}\text { Nova } \\
\text { ureditev }\end{array}$ & $\begin{array}{l}\text { Predlog } \\
\text { strokovne } \\
\text { skupine } \\
\end{array}$ & $\begin{array}{l}\text { Alternativni } \\
\text { predlog strokovne } \\
\text { skupine }\end{array}$ \\
\hline Povprečna velikost & 19.358 & 19.358 & 19.358 & 19.358 \\
\hline Mediana & $18.569,5$ & $18.562,5$ & $19.384,5$ & $19.539,5$ \\
\hline Standardni odklon & $4.704,7$ & $4.171,3$ & $3.029,8$ & $3.410,6$ \\
\hline Koeficient variacije & 24,3 & 21,5 & 15,7 & 17,6 \\
\hline 5 kvantil & 12.806 & 12.942 & 14.433 & 13.334 \\
\hline 95 kvantil & 27.844 & 26.076 & 23.828 & 24.115 \\
\hline Interkvartilni razmik & 6.629 & 6.503 & 4.276 & 5.253 \\
\hline $\begin{array}{l}\text { Variacijski razmik (razlika } \\
\text { med največjim in najmanjšim } \\
\text { volilnim okrajem) }\end{array}$ & 23.749 & 17.045 & 14.086 & 15.082 \\
\hline Največji volilni okraj & $\begin{array}{c}4003- \\
\text { Grosuplje }\end{array}$ & $\begin{array}{l}5001- \\
\text { Celje } 1\end{array}$ & $\begin{array}{l}7001- \\
\text { Šmarje pri } \\
\text { Jelšah }\end{array}$ & $\begin{array}{l}7004 \text { - Slovenska } \\
\text { Bistrica } 1\end{array}$ \\
\hline $\begin{array}{l}\text { Velikost največjega volilnega } \\
\text { okraja }\end{array}$ & 31.694 & 29.705 & 27.706 & 26.631 \\
\hline $\begin{array}{l}\text { Odstopanje največjega volilnega } \\
\text { okraja od povprečja }\end{array}$ & 63,7 & 53,5 & 43,1 & 37,6 \\
\hline Najmanjši volilni okraj & $\begin{array}{l}6009- \\
\text { Hrastnik }\end{array}$ & $\begin{array}{l}1007- \\
\text { Tržič }\end{array}$ & $\begin{array}{l}1011- \\
\text { Idrija }\end{array}$ & 4002 - Ribnica \\
\hline
\end{tabular}




\begin{tabular}{|l|c|c|c|c|}
\hline Kazalec & $\begin{array}{c}\text { Stara } \\
\text { ureditev }\end{array}$ & $\begin{array}{c}\text { Nova } \\
\text { ureditev }\end{array}$ & $\begin{array}{c}\text { Predlog } \\
\text { strokovne } \\
\text { skupine }\end{array}$ & $\begin{array}{c}\text { Alternativni } \\
\text { predlog strokovne } \\
\text { skupine }\end{array}$ \\
\hline $\begin{array}{l}\text { Velikost najmanjšega volilnega } \\
\text { okraja }\end{array}$ & 7.945 & 12.660 & 13.620 & 11.549 \\
\hline $\begin{array}{l}\text { Odstopanje najmanjšega } \\
\text { volilnega okraja od povprečja } \\
\text { (v\%) }\end{array}$ & 59,0 & 34,6 & 29,6 & 40,3 \\
\hline $\begin{array}{l}\text { Razmerje med največjim in } \\
\text { najmanjšim volilnim okrajem }\end{array}$ & $4: 1$ & $2,3: 1$ & $2,0: 1$ & $2,3: 1$ \\
\hline $\begin{array}{l}\text { Stevilo volilnih okrajev, ki od } \\
\text { povprečja odstopajo za manj kot } \\
\text { 15\% (-/+ 15\%) }\end{array}$ & 40 & 41 & 55 & 51 \\
\hline $\begin{array}{l}\text { Število volilnih okrajev, ki od } \\
\text { povprečja odstopajo za manj kot } \\
\text { 25\% (-/+ 25 \%) }\end{array}$ & 60 & 63 & 81 & 76 \\
\hline $\begin{array}{l}\text { Število volilnih okrajev, ki od } \\
\text { povprečja odstopajo za več kot } \\
\mathbf{2 5 \% ~ ( - / + ~ 2 5 \% ) ~}\end{array}$ & 28 & 25 & 7 & 12 \\
\hline
\end{tabular}


Slika 9: Histogrami števila volivcev v volilnih okrajih v analiziranih ureditvah (GURS, 2021; MNZ, 2019; Rogelj in sod., 2019a; 2019b).

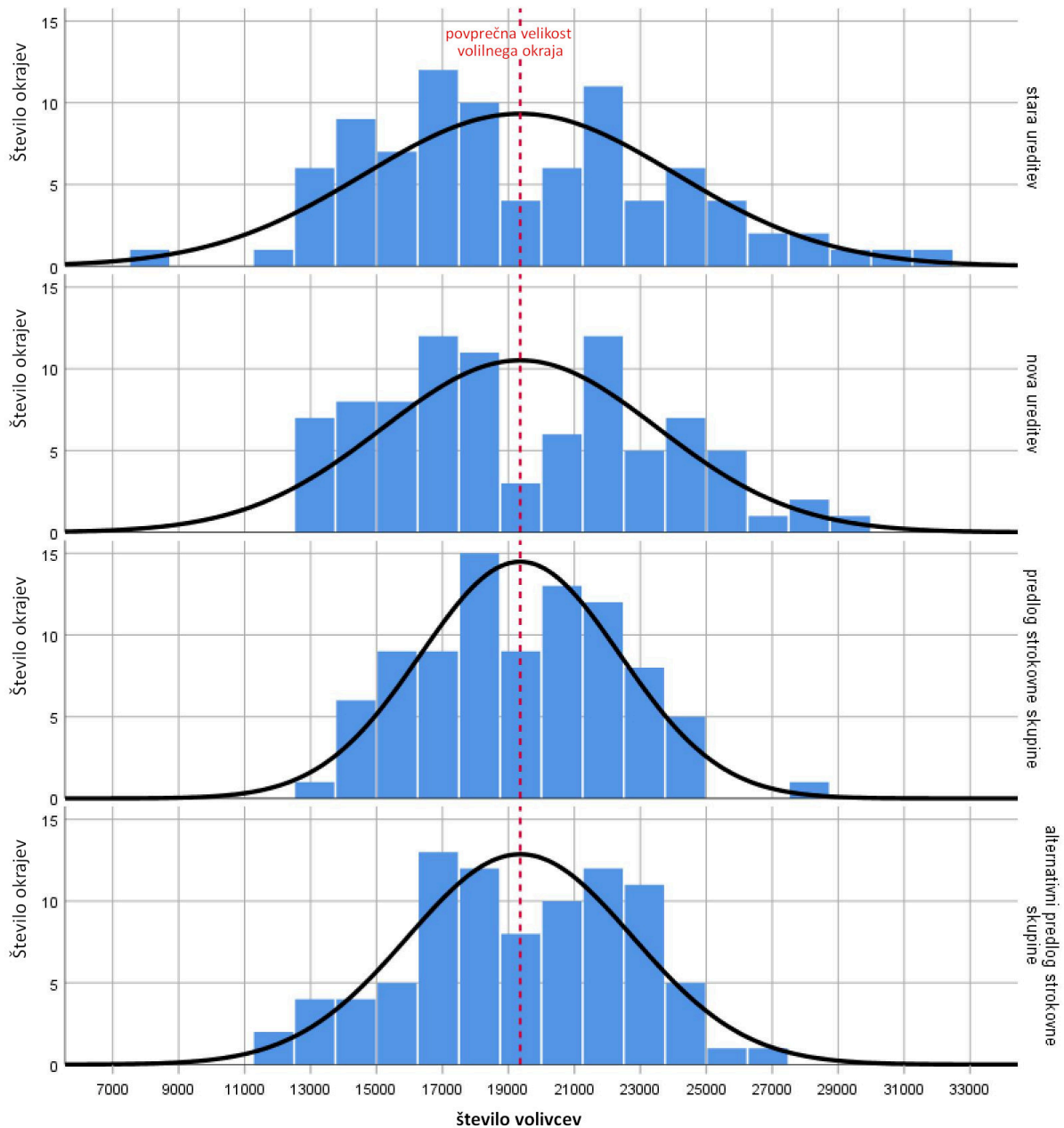

Ocena geografske zaokroženosti je bila narejena s pomočjo prostorske analize usklajenosti meja volilnih okrajev z mejami obstoječih upravno-teritorialnih enot. Stara ureditev je temeljila na mejah občin in krajevnih skupnosti iz leta 1992. Z reformami lokalne samouprave med letoma 1994 in 2012 sta se spremenila tako število kot prostorski obseg občin in krajevnih skupnosti (slednje so bile ponekod odpravljene oziroma nadomeščene s četrtnimi/mestnimi/vaškimi skupnostmi). V stari ureditvi volilnih okrajev je bilo kar štiriindvajset občin razdeljenih na dva ali več okrajev. Pri devetih je bila delitev 
potrebna, saj je število volivcev v njih za več kot $25 \%$ presegalo velikost povprečnega volilnega okraja, pri preostalih je bila delitev nepotrebna (preglednica 3).

Zaradi minimalističnega pristopa $\mathrm{k}$ preoblikovanju volilnih okrajev je nova ureditev odpravila le tri delitve volilnih okrajev (Trbovlje, Šentrupert in Pesnica) (preglednica 3, slika 10). Za odpravo večine drugih bi bil potreben korenitejši poseg v ustroj volilnih okrajev. Izjema so tri občine. Uskladitev občinskih in okrajnih meja na območju občin Bohinj, Ivančna Gorica in Zreče bi zahtevala minimalne spremembe. Še posebno nesmiselna je delitev občine Ivančna Gorica, ki je v novi ureditvi razdeljena celo na dve volilni enoti (medtem ko je večji del občine v VE 4, so bila naselja Pusti Javor, Radanja vas, Sela pri Sobračah, Sobrače in Vrh pri Sobračah skupaj z občino Litija in Šmartno pri Litiji prestavljena v VE 6). Predloga strokovne skupine v večji meri odpravljata nepotrebne delitve občin. Prvi predlog je predvidel odpravo enajstih, alternativni pa kar štirinajstih delitev.

V stari ureditvi so bila poleg občin razdeljena tudi nekatera naselja in krajevne skupnosti (preglednica 3). Medtem ko je delitev štirih največjih naselij (Ljubljana, Maribor, Celje in Kranj) nujna zaradi njihove velikosti, je delitev preostalih popolnoma nepotrebna in nesmiselna. V Ljubljani, Mariboru in Kranju je stara ureditev delila celo nekatere mestne/četrtne/krajevne skupnosti (v Ljubljani je razdeljenih kar 13 od 17 četrtnih skupnosti). Nova ureditev je odpravila le štiri delitve naselij, ohranja pa vse delitve mestnih/četrtnih/krajevnih skupnosti. Nasprotno sta oba predloga strokovne komisije predvidela odpravo vseh delitev naselij (ohranila bi se le delitev naselja Vinarje pri Mariboru, ki je razdeljeno na dve mestni četrti) in večine mestnih/ četrtnih/krajevnih skupnosti (v Ljubljani bi se ohranila delitev mestnih četrti Fužine, Šiška in Bežigrad, ki za več kot 25 \% presegajo velikost povprečnega volilnega okraja). Posledično bi bili volilni okraji na območju Ljubljane in Maribora bolj homogeni, saj bi obsegali le območja mestnih naselij in neposrednega sosedstva (slika 11). 
Preglednica 3: Izbrani kazalci geografske zaokroženosti volilnih okrajev v analiziranih ureditvah (vir: GURS, 2021; MNZ, 2019; Rogelj in sod., 2019a; 2019b).

\begin{tabular}{|c|c|c|c|c|}
\hline Kazalec & Stara ureditev & Nova ureditev & $\begin{array}{l}\text { Predlog stro- } \\
\text { kovne skupine }\end{array}$ & $\begin{array}{l}\text { Alternativni } \\
\text { predlog stro- } \\
\text { kovne skupine }\end{array}$ \\
\hline $\begin{array}{l}\text { Število občin, ki } \\
\text { so razdeljene na } \\
\text { dva ali več volil- } \\
\text { nih okrajev }\end{array}$ & 24 & 21 & 13 & 10 \\
\hline \multirow{2}{*}{$\begin{array}{l}\text { Število razde- } \\
\text { ljenih občin, ki } \\
\text { za več kot } 25 \% \\
\text { presegajo veli- } \\
\text { kost povprečnega } \\
\text { volilnega okraja }\end{array}$} & 9 & 9 & 9 & 99 \\
\hline & $\begin{array}{l}\text { Celje, Domžale, Ko- } \\
\text { per, Kranj, Ljubljana, } \\
\text { Maribor, Nova Go- } \\
\text { rica, Novo mesto, } \\
\text { Velenje }\end{array}$ & $\begin{array}{l}\text { Celje, Domžale, } \\
\text { Koper, Kranj, } \\
\text { Ljubljana, Mari- } \\
\text { bor, Nova Gori- } \\
\text { ca, Novo mesto, } \\
\text { Velenje }\end{array}$ & $\begin{array}{l}\text { Celje, Dom- } \\
\text { žale, Koper, } \\
\text { Kranj, Ljublja- } \\
\text { na, Maribor, } \\
\text { Nova Gorica, } \\
\text { Novo mesto, } \\
\text { Velenje }\end{array}$ & $\begin{array}{l}\text { Celje, Dom- } \\
\text { žale, Koper, } \\
\text { Kranj, Ljublja- } \\
\text { na, Maribor, } \\
\text { Nova Gorica, } \\
\text { Novo mesto, } \\
\text { Velenje }\end{array}$ \\
\hline \multirow{2}{*}{$\begin{array}{l}\text { Število razdelje- } \\
\text { nih občin, ki za } \\
\text { manj kot } 25 \% \\
\text { presegajo veli- } \\
\text { kost povprečnega } \\
\text { volilnega okraja }\end{array}$} & 15 & 12 & 4 & 1 \\
\hline & $\begin{array}{l}\text { Bohinj, Brezovica, } \\
\text { Dol pri Ljubljani, } \\
\text { Hoče-Slivnica, } \\
\text { Ivančna Gorica, Mo- } \\
\text { ravske Toplice, Mur- } \\
\text { ska Sobota, Pesnica, } \\
\text { Ptuj, Renče-Vogrsko, } \\
\text { Šentrupert, Škofljica, } \\
\text { Trbovlje, Velenje, } \\
\text { Zreče in Žalec }\end{array}$ & $\begin{array}{l}\text { Bohinj, Bre- } \\
\text { zovica, Dol } \\
\text { pri Ljubljani, } \\
\text { Hoče-Slivnica, } \\
\text { Ivančna Gorica, } \\
\text { Moravske To- } \\
\text { plice, Murska } \\
\text { Sobota, Ptuj, } \\
\text { Renče-Vogrsko, } \\
\text { Škofljica, Velenje, } \\
\text { Zreče in Žalec }\end{array}$ & $\begin{array}{l}\text { Brezovica, } \\
\text { Grosuplje, Slo- } \\
\text { venska Bistri- } \\
\text { ca, Vrhnika }\end{array}$ & Brezovica \\
\hline \multirow{2}{*}{$\begin{array}{l}\text { Število razde- } \\
\text { ljenih naselij, ki } \\
\text { za več kot } 25 \% \\
\text { presegajo veli- } \\
\text { kost povprečnega } \\
\text { volilnega okraja }\end{array}$} & 4 & 4 & 4 & 4 \\
\hline & $\begin{array}{l}\text { Ljubljana, Maribor, } \\
\text { Celje, Kranj }\end{array}$ & $\begin{array}{l}\text { Ljubljana, Mari- } \\
\text { bor, Celje, Kranj }\end{array}$ & $\begin{array}{l}\text { Ljubljana, } \\
\text { Maribor, Celje, } \\
\text { Kranj }\end{array}$ & $\begin{array}{l}\text { Ljubljana, } \\
\text { Maribor, Celje, } \\
\text { Kranj }\end{array}$ \\
\hline \multirow{2}{*}{$\begin{array}{l}\text { Število razdelje- } \\
\text { nih naselij, ki za } \\
\text { manj kot } 25 \% \\
\text { presegajo veli- } \\
\text { kost povprečnega } \\
\text { volilnega okraja }\end{array}$} & 14 & 10 & 1 & 1 \\
\hline & $\begin{array}{l}\text { Domžale, Knezdol, } \\
\text { Koper, Križe, Kušer- } \\
\text { nik, Nemški Rovt, } \\
\text { Pivola, Ptuj, Spodnje } \\
\text { Hoče, Sveta Gora, } \\
\text { Velenje, Vinarje, } \\
\text { Vrhe, Zgornje Hoče }\end{array}$ & $\begin{array}{l}\text { Domžale, Koper, } \\
\text { Križe, Nemški } \\
\text { Rovt, Pivola, } \\
\text { Ptuj, Sveta Gora, } \\
\text { Velenje, Vinarje, } \\
\text { Zgornje Hoče }\end{array}$ & Vinarje & Vinarje \\
\hline
\end{tabular}




\begin{tabular}{|l|l|l|l|l|}
\hline $\begin{array}{l}\text { Število krajevnih/četrtnih/mestnih skupnosti v največjih naseljih, ki so razdeljene na več } \\
\text { volilnih okrajev }\end{array}$ & 13 & 3 & 2 \\
\hline $\begin{array}{l}\text { Ljubljana (skupaj } \\
\text { 17 četrtnih skup- } \\
\text { nosti) }\end{array}$ & 13 & 6 & 0 & 0 \\
\hline $\begin{array}{l}\text { Maribor (skupaj } \\
\text { 17 krajevnih } \\
\text { skupnosti in } \\
\text { mestnih četrti) }\end{array}$ & 6 & 1 & 0 & 0 \\
\hline $\begin{array}{l}\text { Kranj (skupaj 26 } \\
\text { krajevnih skup- } \\
\text { nosti) }\end{array}$ & 1 & 0 & 0 & 0 \\
\hline $\begin{array}{l}\text { Celje (skupaj 19 } \\
\text { krajevnih skup- } \\
\text { nosti in mestnih } \\
\text { čtrti) }\end{array}$ & 0 & & & \\
\hline
\end{tabular}

Slika 10: Nova ureditev - občine, ki so razdeljene na dva ali več volilnih okrajev.

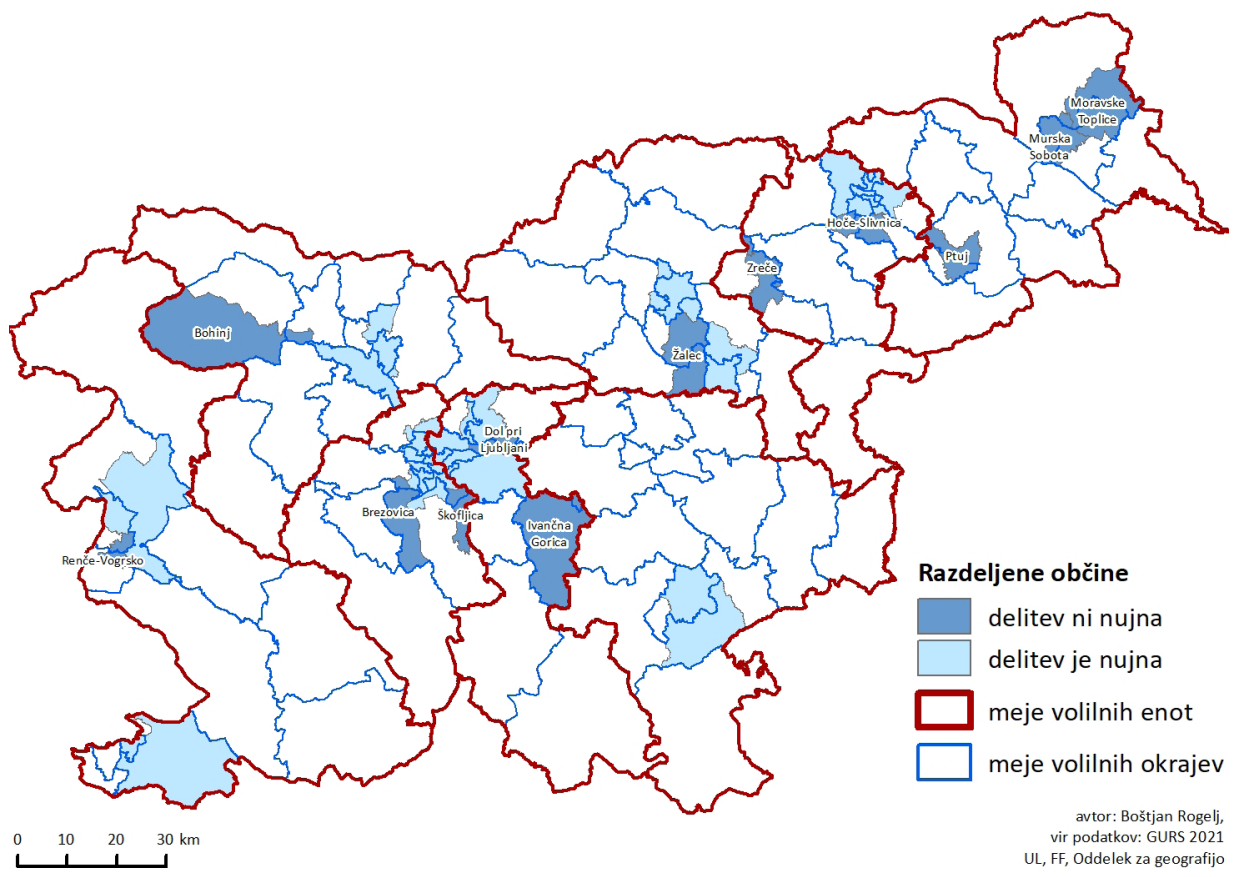


Slika 11: Ureditev volilnih okrajev na območju mestne občine Ljubljana: a) nova ureditev; b) predlog strokovne skupine.
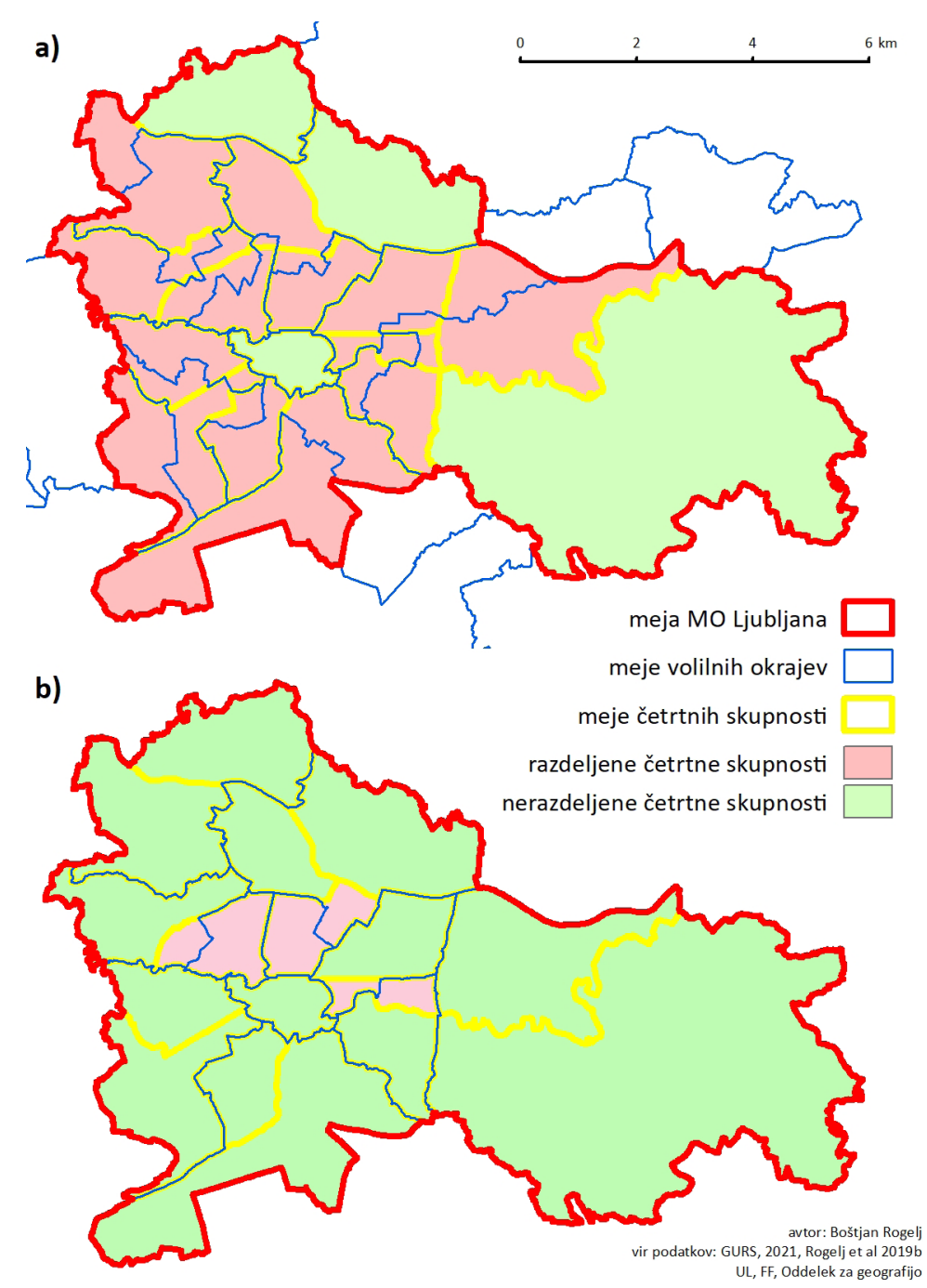


\section{SKLEP}

Iz rezultatov analize je razvidno, da nova ureditev volilnih okrajev temelji na minimalnih spremembah stare ureditve. Posledično ohranja večino njenih problematičnih in nesmiselnih rešitev. Ali to pomeni, da je tudi nova ureditev neskladna $\mathrm{z}$ ustavo? Odgovor na to vprašanje je odvisen od interpretacije ZVDZ-ja in preteklih odločitev Ustavnega sodišča. Že prej smo opozorili, da zakonodaja nikjer ne določa, kakšno je "približno enako število prebivalcev«, prav tako ne definira, kaj je "geografska zaokroženost«.

Zagovorniki minimalnih sprememb zagovarjajo tezo, da mora ureditev volilnih okrajev izpolnjevati vsaj eno merilo 20. člena ZVDZ (tisto o enaki velikosti ali tisto o geografski zaokroženosti). Po njihovem mnenju so neustavne le velike razlike med najmanjšim in največjim volilnim okrajem, pri čemer naj bi zakonodaja dovoljevala celo 50-\% odstopanja od velikosti povprečnega volilnega okraja. Svoje mnenje opirajo na odločitev Ustavnega sodišča RS iz leta 1992, v kateri velike razlike v velikosti volilnih okrajev niso bile označene za protiustavne (Ustavno sodišče RS, 1992). Nova ureditev je zelo podobna ureditvi iz leta 1992. Enaka oziroma zelo podobna sta tako prostorski obseg kot velikost volilnih okrajev.

Zagovorniki temeljitih sprememb nasprotno trdijo, da mora ureditev volilnih okrajev v čim večji meri zadostiti obema zakonskima meriloma. Stara ureditev je bila problematična tako zaradi velikih razlik v velikosti kot zaradi neusklajenosti meja volilnih okrajev z mejami preostalih upravno-teritorialnih enot. Po njihovem mnenju bi morala nova ureditev odpraviti obe pomanjkljivosti, večja odstopanja v velikosti pa naj bi bila dovoljena le zaradi ohranjanja geografske zaokroženosti volilnih okrajev.

Če sledimo interpretaciji zagovornikov minimalnih sprememb, potem je nova ureditev ustrezna in skladna $\mathrm{z}$ ustavo. Če sledimo interpretaciji zagovornikov temeljitih sprememb, pa je nova ureditev neustavna. Kateri interpretaciji bodo sledili ustavni sodniki ob morebitni prihodnji presoji ustavnosti ZDVEDZ-ja, je težko napovedati. Predloga strokovne skupine dokazujeta, da je v okviru zakonskih omejitev mogoče oblikovati velikostno primerljive in hkrati geografsko zaokrožene volilne okraje.

Dosedanje reforme volilnega sistema v Sloveniji so pokazale, da je končni rezultat reformnega procesa $\mathrm{v}$ večini primerov odvisen od specifičnih političnih razmer in partikularnih interesov najmočnejših političnih strank (Rogelj, 2011). Omenjena dejavnika sta odločilno vplivala tudi na zadnjo reformo. Volilni okraji so zelo pomembni pri delitvi poslanskih mandatov (mandati, ki jih stranka osvoji na ravni volilnih enot, se dodelijo strankarskim kandidatom $\mathrm{z}$ največjim deležem glasov v volilnem okraju). Izkušnje kažejo, da je obstoječi volilni sistem relativno predvidljiv. Predvsem večje politične stranke $\mathrm{z}$ daljšo tradicijo zelo dobro vedo, $\mathrm{v}$ katerih volilnih okrajih je možnost za izvolitev njihovih kandidatov velika, v katerih pa ne. Vodstva strank lahko $\mathrm{z}$ razporeditvijo izbranih kandidatov $\mathrm{v}$ »izvoljive « volilne okraje odločilno vplivajo na dodelitev poslanskih mandatov. Večje spremembe v ureditvi volilnih okrajev bi vsaj začasno ustvarile razmere, $\mathrm{v}$ katerih bi bila izvoljivost posameznih kandidatov veliko 
bolj negotova. Zato ni presenetljivo, da so se nekatere stranke (predvsem SDS in DeSUS) z vsemi sredstvi borile za minimalne spremembe sistema.

$\mathrm{Na}$ koncu velja opozoriti, da so bili volilni okraji vključeni v volilni sistem zato, da bi volivci odločilno vplivali na dodelitev poslanskih mandatov. Dosedanje volitve so pokazale, da ni tako. Če bi politiki resnično želeli, da bi imeli volivci odločilen vpliv na dodelitev poslanskih mandatov, potem bi bilo smiselno volilne okraje v celoti odpraviti oziroma jih nadomestiti $\mathrm{z}$ uvedbo prednostnega glasu. S tem volivec ne bi bil prisiljen voliti kandidata, ki mu ga vsili vodstvo politične stranke.

\section{Literatura in viri}

Gaber, S., 1996. Volilni sistemi : zbornik. Ljubljana: Krtina.

Grad, F., 2004. Volitve in volilni sistem. Ljubljana: Uradni list Republike Slovenije.

GURS, 2019. Register prostorskih enot. URL: https://www.e-prostor.gov.si/brezplacni-podatki/ (citirano 25. 4. 2019).

GURS, 2021. Register prostorskih enot. URL: https://www.e-prostor.gov.si/brezplacni-podatki/ (citirano 30. 11. 2021).

Hadjar, A., Beck, M., 2010. Who does not participate in elections in Europe and why is this?: A multilevel analysis of social mechanisms behind non-voting. European Societies, 12, 4, str. 521-542. DOI: 10.1080/14616696.2010.483007.

Krašovec, A., 2007. Volilne študije. Ljubljana: Fakulteta za družbene vede.

Lijphart, A., 1994. Electoral systems and party systems : a study of twenty-seven democracies, 1945-1990. Oxford: Oxford University Press.

McAllister, I., Makkai, T., 1993. Institutions, society or protest? Explaining invalid votes in Australian elections. Electoral Studies, 12, 1, str. 23-40. DOI: 10.1016/02613794(93)90004-4.

MMC RTV SLO, 2021. Zelena luč poskusu uskladitve glede volilne zakonodaje. URL: https://www.rtvslo.si/slovenija/zelena-luc-poskusu-uskladitve-glede-volilne-zakonodaje/568786 (citirano 11. 2. 2021).

MNZ, 2019. Centralni register prebivalstva - število volivcev po hišnih številkah.

Norris, P., 2004. Electoral engineering voting rules and political behavior. Cambridge: Cambridge University Press.

Pogorelec, J., 1998. Sistem volitev v Državni zbor: nekaj predlogov za njegovo izboljšanje. Pravna praksa.

Power, T. J., Garand, J. C., 2007. Determinants of invalid voting in Latin America. Electoral Studies, 26, 2, str. 432-444. DOI: 10.1016/j.electstud.2006.11.001.

Razpotnik, B., 2020. V prvem polletju 2020 dve tretjini več medobčinskih selitev kot v istem obdobju leta 2019. URL: https://www.stat.si/StatWeb/news/Index/9232 (citirano 6. 12. 2021).

Ribičič, C., 1996. Osebnost kandidatov in sorazmerna zastopanost strank. V: Gaber, S. (ur.). Volilni sistemi. Ljubljana: Krtina, str. 283-303. 
Rogelj, B., 2011. Političnogeografska analiza volilnega sistema volitev v Državni zbor Republike Slovenije. Doktorska disertacija. Ljubljana: Univerza v Ljubljani.

Rogelj, B., 2012. Ureditev volilnih enot v državnozborskem volilnem sistemu. Dela, 37, str. 107-128.

Rogelj, B., Krevs, M., Veršič, A., Prešern, M., 2019a. Predlog sprememb območij volilnih enot in volilnih okrajev (Poročilo Medresorske delovne skupine za pripravo sprememb in dopolnitev ZVDZ). Ljubljana.

Rogelj, B., Krevs, M., Veršič, A., Prešern, M., 2019b. Dopolnjen predlog sprememb območij volilnih enot in volilnih okrajev (Poročilo Medresorske delovne skupine za pripravo sprememb in dopolnitev ZVDZ). Ljubljana.

Ustavno sodišče RS, 1992. Odločba U-I-128/92. Ljubljana.

Ustavno sodišče RS, 2003. Odločba U-I-226/00. Ljubljana.

Ustavno sodišče RS, 2018. Odločba U-I-32/15-56. Ljubljana.

Zakon o spremembah in dopolnitvah Zakona o določitvi volilnih enot za volitve poslancev v državni zbor - ZDVEDZ-B. 2021. Uradni list RS, 29/21. Ljubljana.

Zakon o volitvah v državni zbor. 2017. Uradni list RS, 23/17. Ljubljana.

ZRSS [Zavod Republike Slovenije za statistiko], 1994. Rezultati raziskovanj - volitve 1992 (št. 600). Ljubljana.

\section{IS THE NEW REGULATION OF CONSTITUENCIES FOR PARLIAMENTARY ELECTIONS IN SLOVENIA CONSTITUTIONAL?}

\section{Summary}

In national elections the territory of the Republic of Slovenia is divided into eight electoral districts (volilna enota). Each of them is subdivided into 11 constituencies (volilni okraj). In total, the country comprises 88 constituencies. Constituencies are very important for the division of parliamentary seats. The seats won by a party at the district level are allocated to the party candidates with the highest share of the vote in the constituency.

The law stipulates that constituencies must have approximately the same number of inhabitants and that their creation must take into account geographical consistency as well as common cultural and other characteristics. It is important to note that nowhere does the law set a maximum variation in the number of inhabitants. Nor does it specify which criteria must be taken into account in order to satisfy the criterion of geographical consistency.

In 2018, the Constitutional Court of the Republic of Slovenia ruled that the system of constituencies was not compatible with the Constitution. The large differences in 
the number of voters between constituencies, as well as their geographic inconsistency, were considered problematic. The latter was most directly manifested in the mismatch between constituency and municipal boundaries. This decision triggered a reform of the electoral legislation, as part of which several proposals for a new electoral district system were put forth.

The Ministry of Public Administration formed an expert working group which in 2019 prepared three proposals for a new system of constituencies (Figure 5, 6, 7 and 8) (Rogelj et al., 2019a; 2019b). Following the change of government in March 2020, the expert group was disbanded, and the drafting of new legislation was taken over by the new government coalition led by the Slovenian Democratic Party (SDS). While the expert group advocated a radical overhaul of the constituency system, the SDS advocated minimal changes (MMC RTV SLO, 2021). The SDS representatives argued that the existing system was mostly adequate, contending that there were only a handful of problematic constituencies varying significantly in size (in terms of the number of voters).

In line with this position, the Ministry of Public Administration prepared a proposal at the beginning of 2021, which foresaw a change in the boundaries of 14 constituencies and three revisions to the boundaries of electoral districts (Figures 2, 3 and 4). The proposal was voted through despite a number of concerns about its suitability and constitutionality and without broad political consensus.

Our research focused on the constitutionality of the adopted system. We wanted to know whether it remedies the unconstitutional situation and to what extent it complies with the legal provisions on the size and geographical consistency of constituencies. To this end, we carried out a comparative spatial and statistical analysis, comparing the new system with the previous one and with the two proposals put forth by the expert working group.

The analysis (Table 2, Figures 4, 6, 8 and 9) shows that the new system has significantly reduced the difference between the two most outlying constituencies but has done very little to eliminate the substantial variability in constituency size. Figures 4 and 9 show that the new system still features a large number of constituencies that deviate by more than $25 \%$ from the average, while there are only around half of all consistencies deviating from the average by less than $15 \%$. In contrast, both proposals of the expert group have not only eliminated the large size differences, but also the large variability in size (Figures 6,8 and 9). The basic proposal envisaged only seven constituencies deviating by more than $25 \%$ from the average, of which only one (Šmarje pri Jelšah) deviated by more than $30 \%$. The alternative proposal envisaged slightly larger deviations, as it would have maintained or created some very small constituencies (Ribnica, Rogaška Slatina, Izola and Ivančna Gorica).

Assessments of the geographical consistency of constituencies were made through a spatial analysis of the alignment of constituencies with the boundaries of existing administrative-territorial units (Table 3, Figures 10 and 11). The old system was based on the 1992 municipal and local authority boundaries. The reform of local 
self-government has led to a number of discrepancies between constituency and municipal boundaries. Under the old system, as many as twenty-four municipalities were divided into two or more constituencies. In nine of them, the division was necessary because the number of voters in them exceeded the size of the average electoral district by more than $25 \%$, while in the others the division was unnecessary.

Given the minimalist approach to constituency redistricting, the new system has abolished only three constituencies (Trbovlje, Šentrupert and Pesnica). The proposals of the expert group foresaw the abolition of most of the unnecessary municipal divisions. The first proposal would have entailed the abolition of eleven divisions, while the alternative proposal foresaw the abolition of as many as fourteen divisions.

Under the old system, divisions occurred not only in municipalities but also in some settlements and local communities (Table 3, Figure 10). While the division of the four largest settlements (Ljubljana, Maribor, Celje and Kranj) is necessary because of their size, the division of others is completely unnecessary and pointless. In Ljubljana, Maribor and Kranj, the old system even divided some of the city/borough/local districts. The new system has abolished only four divisions of settlements but retains all the divisions of city/borough/local districts. In contrast, both proposals of the expert group foresaw the abolition of all unnecessary divisions of settlements and most among city/borough/local wards. Thus, under these proposals the electoral districts in Ljubljana (Figure 11) and Maribor would be more homogeneous, as they would cover only the areas of the urban settlements and the immediate neighbourhood.

The results of the analysis show that the new system of constituencies is based on the old system with minimal changes. As a result, it retains most of its problematic and nonsensical outcomes. Does this mean that the new system is also incompatible with the Constitution? The answer to this question depends on the interpretation of the legislation and past decisions of the Constitutional Court.

If we follow the interpretation of the advocates of minimum changes, then the new system is appropriate and compatible with the Constitution. If we follow the interpretation of the advocates of more fundamental changes, the new system is unconstitutional. It is difficult to predict which interpretation the constitutional judges will follow in any future review of the constitutionality of the system. The proposals of the expert group demonstrate that it is possible to create constituencies that are comparable in size and at the same time geographically consistent, within the confines of the law.

The results of the analysis show that both proposals of the expert group meet the legal criteria to a much greater extent than the new system of constituency. Why did members of Parliament decide to adopt the minimum changes? The reasons for this can be traced back to political calculation on the part of the government parties. The existing electoral system is relatively predictable. Especially the larger political parties with a longer tradition know very well in which constituencies their candidates are likely to be elected and in which they are not. By allocating their preferred candidates to 'electable' constituencies, party leaderships can decisively influence the allocation 
of parliamentary seats. Major changes in the system of constituencies would, at least temporarily, create a situation in which the electability of individual candidates would be much more uncertain. It is therefore not surprising that some parties have fought by all means for minimal changes to the system.

Finally, it should be noted that constituencies were included in the electoral system in order to give voters a decisive influence on the allocation of parliamentary seats. Elections to date have shown that this is not the case. If politicians really wanted the electorate to have a decisive influence on the allocation of parliamentary seats, then it would make sense to abolish constituencies altogether, or to replace them with the introduction of preferential voting. This would prevent the electorate from being forced to vote for a candidate imposed by the leadership of a political party. 